FE DER A L EN ER G Y MA N A G E M N T PROG R A M

\title{
Energy Efficiency Solution for the Chet Holifield Federal Building
}

Utility partnership upgrades energy system to help meet GSA energy-saving goals

\section{Overview}

The Chet Holifield Federal Building in Laguna Niguel, California, is one of the first Federal facilities to implement a comprehensive program for energy and water efficiency. It is the General Services Administration's (GSA) third-largest building and consists of a main office building that houses the Internal Revenue Service, the National Archives, and other Federal tenants. It also includes a plant services building that contains offices, workshops, and garage bays, and a central plant that houses the equipment for the cooling system used for the main building.

Through its ENVEST program, Southern California Edison (SCE) is paying all up-front costs to completely overhaul the 30-year-old building's energy and water systems. The estimated annual energy savings is $\$ 640,000$.

\section{Background}

SCE's ENVEST program was designed to work with Federal facilities to implement energy conservation projects that help them meet the requirements of the Executive Order on Energy Efficiency and Water Conservation at Federal facilities.

In November 1993, GSA and SCE agreed to investigate the potential benefits of an integrated energy efficiency solution for the Chet Holifield facility. After reviewing the preliminary assessment, GSA, with assistance from the U.S. Department of Energy's Federal Energy Management Program and the National Renewable Energy Laboratory, decided to move forward with the project. SCE then conducted a feasibility study to assess the economic and operational effects of energy system retrofits.

\section{Project summary}

The integrated energy efficiency project at Chet Holifield resulted from a feasibility study by SCE and an agreement between GSA and SCE. In March 1994, GSA and SCE signed a work agreement, and work on the facility began in September of that year.

The project began with an SCE feasibility study of the building systems. SCE performed the study with input from those responsible for operating and maintaining the facility. The analysis evaluated the cost and energy benefits of thermal energy storage; lighting; heating, ventilating, and air conditioning; and primary heating and cooling equipment auxiliaries. SCE estimated that the annual electric consumption at the facility could be reduced from 14,842 MWh to 11,069 MWh (a 25\% reduction), and gas from 10,090 MBtu to 9,040 MBtu (a $10 \%$ reduction).

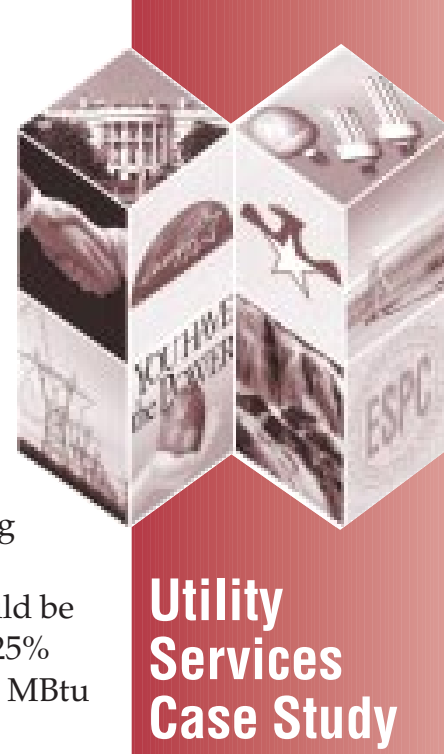

From recommendations of the feasibility study, the following conservation measures were taken at Chet Holifield:

- Installing a thermal energy storage system

- Rebalancing the air distribution system

- Replacing fan motors

- Installing variable-frequency drives on hot water pumps

- Upgrading the energy management control system.

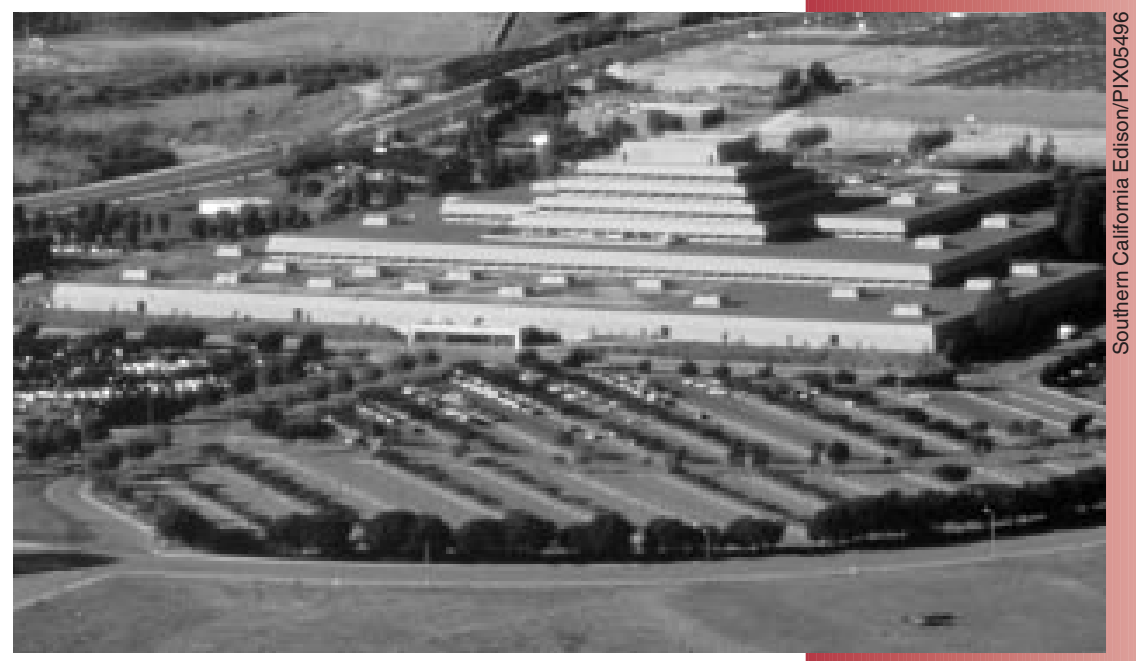

The Chet Holifield Federal Building is a 1997 Federal Energy Savers Showcase award winner.

\section{Benefits of utility contracting}

SCE provided an in-depth feasibility study, engineering and design, construction, commissioning, and management services for this upgrade. It also financed the entire capital cost (\$3.8 million), which will be repaid from the energy savings.
U.S. Department of Energy

Office of Energy Efficiency and Renewable Energy 
To date, savings have been even greater than initially estimated. Electrical consumption dropped dramatically, which translates into an annual Btu savings of more than 16 billion.

\section{Lessons learned}

\section{Detailed contract}

In a project of this size, there are typically several change orders throughout the contract term that increase the cost of the overall project. As a result of a carefully detailed and well written contract, only two change orders were required, saving valuable time and staff resources. And, these change orders actually resulted in a net decrease in the contract price, an extremely rare occurrence.

\section{Human resources}

GSA on-site staff took an active role in overseeing the effort, which saved travel time and money on the part of regional staff who usually oversee projects. In addition, having on-site staff available for coordination and oversight greatly improved contract performance.

\section{Planning}

About the time of the upgrades, one tenant added a second shift, which changed on-peak use to off-peak use. Unfortunately, there was no way the GSA could have foreseen the change in time of energy use. This shows that even the best intentions do not always work as well as planned.

\section{Looking ahead}

It is anticipated that gas consumption will drop about $10 \%$ and electricity consumption by about $25 \%$.

In addition to these specific benefits, the building staff will be comprehensively trained in a modern energy management control system. This system will give GSA better control of the building's operating, energy, and comfort needs.

More dollar savings will be realized as well. In February 1998, GSA refinanced the SCE loan at a lower interest rate through the Bonneville Power Administration. Throughout the life of the contract, hundreds of thousands of dollars will be saved.

Water conservation measures are also planned and are anticipated to cut water use by about 25 million gallons.

\section{Monthly project savings}

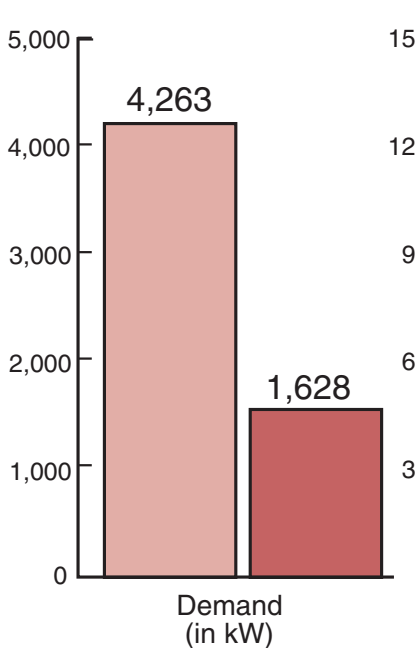

Before (1993)

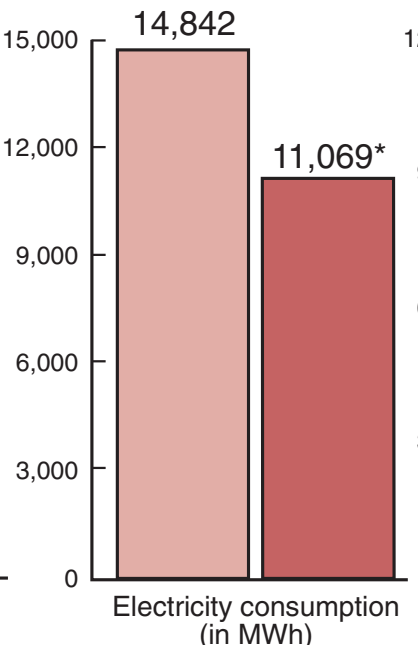

(in MWh)

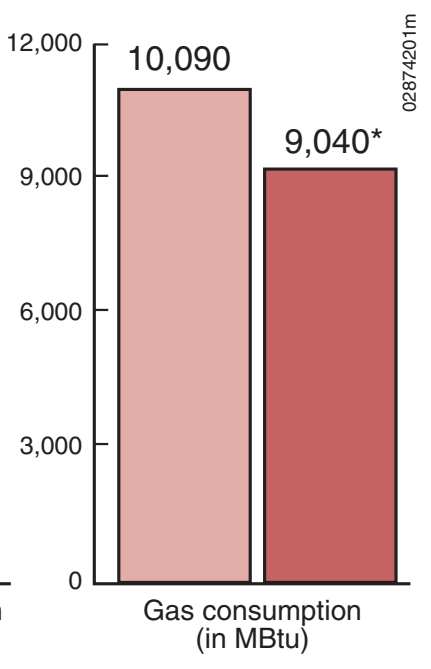

* Estimate from SCE's Integrated Solutions Proposal, July 1994.

\section{For More Information}

FEMP Help Desk:

(800) DOE-EREC (363-3732)

Fax: (202) 586-3000

Internet: http:/ / www.eren.doe.gov/femp

Brad Gustafson

Utility Services Program Manager

DOE FEMP

(202) 586-2204

For more information about the project, contact:

Mary Colvin

National Renewable Energy Laboratory

(303) 384-7511

FEMP Help Desk:

800-DOE-EREC

(363-3732)

Internet:

http://www.eren.doe. gov/iemp

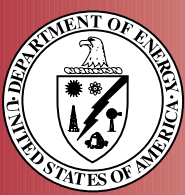

Produced for the

U.S. Department

of Energy by the

National Renewable

Energy Laboratory,

a DOE national

laboratory

DOE/G0-102000-1097

Printed with a renewable-source ink on paper containing at least $50 \%$ wastepaper, including $20 \%$ postconsumer waste 